\title{
Improving the Effectiveness of the Consumer Product Safety System: Australian Law Reform in Asia-Pacific Context
}

\section{Nottage ${ }^{1}$ (ID}

Received: 16 February 2020 / Accepted: 10 May 2020 / Published online: 10 June 2020

(C) Springer Science+Business Media, LLC, part of Springer Nature 2020

\begin{abstract}
The Australian government is undertaking public consultations over possible improvements to the 2010 Australian Consumer Law (ACL) regime, including again the idea of adding a European-style general safety provision (GSP). To bolster the case for such reform, Part 2 of this paper analyses 2017-2019 data trends from the OECD Global Recalls Portal for Australia compared with several comparable economies, especially in the Asia-Pacific region where Australia now has most of its trade and investment links. The analysis finds a persistently high per capita recall rate for Australia, compared with several jurisdictions including Korea, Japan, and especially the USA. However, the analysis identifies various legal and other factors across the jurisdictions that impact on interpreting such data. Part 3 therefore begins by highlighting some more specific patterns uncovered from an ongoing joint research project comparing child product safety trends particularly in Australia and the USA. It highlights various concerns regarding recalls in Australia, as well as weaknesses in Australia's ACL regime (in addition to the lack of a GSP), in coordinating with sector-specific regulation, and in private law mechanisms that could more indirectly promote consumer product safety. Some estimated economic costs from current levels of reported injuries, as well as of many recalls, further reinforce the case for adding a GSP. Part 4 concludes that this improvement to the ACL could be combined with some of the other reform options outlined by the Australian government's Consultation Regulatory Impact Statement, as well as the introduction of a novel "product safety substantiation order" power. The conclusions and analysis should be helpful for other jurisdictions considering product safety law reforms in an increasingly globalized and digital economy, and draw already on comparisons with regulatory regimes and issues particularly in the Asia-Pacific region.
\end{abstract}

Keywords Consumer law · Product safety regulation · Product liability $\cdot$ Children's products . Safety comparative law $\cdot$ Asian law

\section{Nottage}

luke.nottage@sydney.edu.au

Extended author information available on the last page of the article 
On 8 October 2019, the Australian federal government, through the Treasury, released for public consultation a Consultation Regulatory Impact Statement (RIS) on "Improving the Effectiveness of the Consumer Product Safety System." It sought submissions on 30 November on how the Australian Consumer Law (ACL) might be amended to improve consumer product safety regulation nationwide. The Consultation RIS set out six options ranging from doing nothing and better education through to introducing a European-style general safety provision (GSP) requiring suppliers to put only safe products onto the market (Treasury 2019a, p. 8).

The possibility of adding a GSP derives from a review of the ACL commissioned by Australian ministers for consumer affairs in late 2015 and carried out over 2016-2017 (Treasury n.d.). The ACL review was required by the 2009 Intergovernmental Agreement between the federal and state/territory governments, which also committed them to reharmonizing consumer law nationwide by adopting the same substantive law (ACL) while allowing state/territory regulators to retain enforcement powers (Council of Australian Governments 2009). The ACL Review Final Report in early 2017 set out many recommendations for reform, ${ }^{1}$ divided into three categories. The first comprised "non-legislative regulator actions," being mostly better information or guidance concerning the existing ACL. Examples include clarification of:

- When a product is "unsafe" and therefore lacking the mandatory consumer guarantee of "acceptable quality," thus generating primarily private law rights to relief from affected users (guidance recently finalized in CAANZ 2019);

- The scope of suppliers' mandatory reporting obligations (added to the ACL in 2010), especially the timelines and triggers of "use or foreseeable misuse" of products causing "serious injury or illness" (interpreted, e.g., in Nottage 2011).

The second category comprised "well-developed legislative proposals that do not require [RIS]." These include:

- Clarifying and strengthening the longer-standing ACL requirement to report to regulators "voluntary recalls," by adding a statutory definition and increasing penalties to make them proportionate (proposal 7);

- Strengthening Australian Competition and Consumer Commission (ACCC) powers to obtain information about product safety not only from suppliers (proposal 8).

The third category was "legislative proposals requiring further development and/or [RIS]." A key topic was the introduction of a general safety provision that would require traders to ensure the safety of a product before it enters the market including:

- a flexible and less prescriptive approach to compliance by reference to product safety standards (for example, a 'safe harbour' defence to a breach of the general safety provision); and

- a penalty regime for breaches of the general safety provision, consistent with the ACL's penalties regime (proposal 6).

\footnotetext{
${ }^{1}$ For general updates on progress in implementing these recommendations, see Consumers' Federation of Australia (2019), Tracking Calendar. Retrieved from http://consumersfederation.org.au/topics/consumer/aclreview/tracking-calendar/ (accessed 5 May 2020); Australian Consumer Law (2019), year in review. Retrieved from https://consumerlaw.gov.au/australian-consumer-law/year-review (accessed 5 May 2020).
} 
A helpful summary of reforms under all three categories has been compiled by Consumer Affairs Australia and New Zealand (2017, pp. 100-102).

The October 2019 Consultation RIS listing six options for re-regulating consumer product safety therefore falls into the third and last category of potential reforms to the ACL. However, the idea of adding a GSP to Australian law should be seen in a longer historical context (Nottage 2018). The federal government first took note of the GSP introduced by the EU's General Product Safety Directive in 1992 (Directive 92/59/EEC, Art. 3), especially after the Directive was strengthened in 2001 (Directive 2001/95/EC) notably by adding a broad accident reporting obligation on suppliers. However, inquiry reports by Australia's Productivity Commission finalized in 2006 on product safety (Productivity Commission 2006) and in 2008 recommending a nationwide ACL (Productivity Commission 2008) ended up instead proposing improvements to Australia's consumer product safety law regime other than a GSP. There was and remains little awareness in Australia that the EU Directive's GSP was transplanted also in Asia to a former Portuguese colony (Macau) and a former British colony (Hong Kong), nor that the Directive had been influenced by a GSP enacted already by the UK in the Consumer Protection Act 1987, which in turn is restated in Malaysia's Consumer Protection Act 1999. However, policy-makers in Australia have started to realize that the EUstyle GSP had been introduced in the Canada Consumer Product Safety Act in 2010, and then partially in Singapore through its Consumer Protection (Consumer Goods Safety Requirements) Regulations 2011 (Nottage et al. 2019, Chapter 3).

Given this historical and comparative backdrop, has the time finally come for Australia also to add an EU-style GSP, or some variant? If so, the ACL amendment would first need to be introduced by the federal parliament, then copied into state/territory implementation legislation, having secured consent by the former and a majority of states under the 2009 Intergovernmental Agreement. As well as this complication for consumer law reform, the federal government nowadays always has a busy parliamentary agenda. This will be exacerbated by many legislative amendments that had planned for introduction over 2020 following recommendations of the (2017-2018) Royal Commission into Misconduct in the Banking, Superannuation and Financial Services Industry (Treasury 2019b), and further delays can be expected because of the global COVID-19 pandemic since early 2020. Accordingly, ACL amendments to enhance consumer product safety would come from 2021 at the earliest. Further, of course, the final RIS or then the legislators may yet abandon altogether the option of introducing a GSP.

To assess this reform proposal, it is useful to examine consumer product safety trends in Australia compared with similar economies especially in the Asia-Pacific region. That is where Australia has had its closest trade and investment links for many decades, increasingly underpinned by free trade agreements (FTAs) (see, e.g., Department of Foreign Affairs and Trade n.d.; Australian Trade and Investment Commission n.d.). Australia also has joined growing regulatory cooperation and broader "transgovernmentalist" network activity in Asia (Nottage et al. 2019, Chapter 1). Aligning with comparable jurisdictions globally, and especially in the Asia-Pacific region, is likely to yield significant economic and other benefits.

This paper therefore begins in Part 2 by briefly comparing patterns in consumer product recalls in Australia, especially over the 2017-2019 as reported in the OECD (2020) Global Recalls Portal. It notes similarities with Canada, but fewer recalls per capita in Korea, and far fewer recalls than in the UK, the USA, and Japan. Australia's recalls also encompass a high proportion of children's products (especially toys/games and clothing), with around two thirds identified as from the People's Republic of China (PRC). Safety failures for children's 
products are a particular concern, because children are less able to guard themselves against risks or deal with the consequences. Higher volumes and rates of voluntary recalls than in comparable economies arguably indicate more risks and resources being wasted, especially if they are increasing without evidence, for example, of stricter product monitoring or enforcement activity by regulators, although various caveats are discussed regarding assessments of such recalls data. Nonetheless, this preliminary comparison suggests that Australia is indeed ripe for regulatory reform, including adding an EU-style GSP.

Part 3 turns to a closer examination of some issues and options set out in the Consultation RIS. It adds key findings from some more detailed empirical analysis comparing recalls in Australia and the USA, for an ongoing joint research project comparing child product safety regulation. ${ }^{2}$ It highlights socio-economic and legal problems with Australia's current ACL regime, problems with the latter's interaction with sector-specific regulation, and diminishing impact from product liability lawsuits as a key alternative mechanism for incentivizing suppliers to put safe products on the market. Part 3 also suggests that the Consultation RIS estimate of economic costs associated with unsafe products is likely understated, while there would be considerable economic benefits through closer harmonization of Australian law with the regulatory regimes of its major trade and investment partners.

Part 4 therefore concludes that Australia should introduce a GSP (given as Option 6 in the Consultation RIS). In addition, but not as an alternative because these do not place sufficient obligations on suppliers to pro-actively manage their product risks, Australia should introduce new powers for consumer regulators:

- To ban unsafe products, instead of bans by Ministers (Option 3);

- To issue orders against conduct causing or likely to cause significant consumer detriment (inspired by new product intervention powers for financial products: Option 6).

If and when adding Options 3 and/or 4 to Option 6, a new "product safety substantiation order" power could be introduced for Australia's consumer affairs regulators too.

\section{Australia Compared: Preliminary Analysis from OECD Recalls Data}

The OECD Recalls Portal was established in 2012. It includes information on mandatory and voluntary consumer product recalls issued by a governmental body that have been made publicly available. Mandatory recalls are usually very rare, because suppliers are encouraged by regulators first to undertake a voluntary recall. There were 25695 recalls reported as of 9 December 2019. Using this database, the OECD Global Awareness Campaign on Product Recalls (21-25 October 2019) (OECD 2019), coordinated with the assistance of the ACCC and European Commission, noted that:

Over the past decades, the volume of consumer product recalls has been increasing steadily worldwide, affecting millions of non-food products ranging from electronic devices, toys and childcare equipment to household appliances and automobiles.

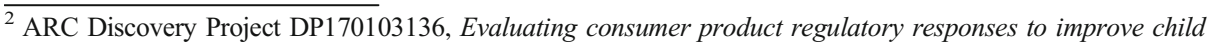
safety.
} 
In the year 2018 alone, over 3700 product recall notifications were submitted by 39 jurisdictions on the OECD Global Recalls portal. Yet consumers' reactions to recalls remain low in most jurisdictions, some achieving response rates as low as $3 \%$. As a result, a large proportion of products that have been the subject of a recall remain in consumers' homes, exposing them to injuries or even risk of death.

Around 20 countries took part in the OECD's October 2019 Global Awareness Campaign on Product Recalls, which aimed to:

- assist consumers in bridging the gap between being aware of a recall and reacting to it;

- enhance business understanding of how to effectively communicate recalls to consumers.

The ACCC was also involved in producing an "Infographic" for that Campaign, noting 3720 total recalls in 2018 as well as averages and some distinctive trends over 2015-2017 for some countries (OECD n.d.).

Jurisdictions providing recall data to the Portal are mostly developed (OECD member) states. Some members of the Association of Southeast Asian Nations (ASEAN) now contribute data, as recommended in late 2014 in a consultancy project report on regional consumer law harmonization (Nottage 2014). Yet, reports remain sparse (208 as of 9 December 2019) and only from seven of the 10 member states (mostly from Indonesia, Singapore, Vietnam, and the Philippines). In addition, some of the reports (e.g., from Singapore ${ }^{3}$ ) do not seem to involve actual recalls in that jurisdiction.

Even developed states vary in terms of recalls data provided to the Portal, notably regarding the starting dates. For example, Japan (a major trading partner for Australia) has provided 449 reports dating back to 1969 . However, Japan reported only 8 recalls in total through to 2001 , then around 3-6 annually from 2002 to 2006, before a jump to 18 reports in 2007, with the $\mathrm{OECD} / \mathrm{ACCC}$ Infographic confirming an average of 90 recalls reported each year over 20152017 (OECD n.d.).

By contrast, the Republic of Korea, as a comparable economy but with under half the population of Japan, reports recalls only from 20 January 2017 (totalling 1092 through to 9 December 2019). The Infographic noted that 320 products were recalled in 2018, including "nearly 90 slime products" (which attracted particular attention from regulators and the media; see, e.g., Lee 2018). It is unclear where the Infographic sourced an average of " 870 " recalls annually for 2015-2017, as there are no reports from Korea on the OECD Portal before 20 January 2017, which shows instead 328 recalls for that year. In addition, a Korean government recalls webpage shows recalls of 482 for 2015 and 445 for 2016. ${ }^{4}$ The Infographic's annual average of 870 for 2015-2017, for Korea (OECD n.d.), seems unusually large and therefore inaccurate.

To better compare patterns in recalls, including some other important trading partners for Australia in the Asia-Pacific region, Table 1 incorporates OECD Portal data from the same starting date as Korea (20 January 2017) through to 9 December 2019, so for almost 3 years. The "recalls" total for Australia has to be reduced from 1585 because, unlike the other selected

\footnotetext{
${ }^{3}$ See, e.g., a report to the Portal from Singapore that Australia's ACCC "recalls toys from Daiso Industries (Australia) Pty Ltd" (OECD 2017). This may be provided as a warning to Singaporean and other consumers that the (Japanese) Daiso chain may be supplying the same products in their jurisdictions.

${ }^{4}$ Retrieved from http://www.safetykorea.kr/recall/recallBoard (accessed 5 May 2020).
} 
Table 1 Patterns in OECD-reported recalls: Australia compared

\begin{tabular}{|c|c|c|c|c|}
\hline 1. Jurisdiction & 2. Population ${ }^{\mathrm{a}}$ & 3. Recalls ${ }^{b}$ & 4. "Child" product recalls & $\begin{array}{l}\text { 5. Origin of recalled } \\
\text { products (for } 4 . \text {.) }\end{array}$ \\
\hline A. Australia & 25 million & $\begin{array}{l}(1585-844) \\
=741\end{array}$ & $\begin{array}{l}298 \text { (40\% of } 741) \text { (toys } 85, \\
\text { furniture } 47 \text {, clothing } 45, \\
\text { sporting } 40, \text { healthcare } 29)\end{array}$ & $\begin{array}{l}\text { China } 187 \text { ( } 62 \% \text { of } 298) \\
\text { India } 9 \\
\text { Indonesia } 7 \\
\text { Australia } 8\end{array}$ \\
\hline B. Canada & 37 million & 1254 & $\begin{array}{l}476(38 \%) \text { (toys } 134, \\
\text { clothing } 117, \text { furniture } \\
76, \text { sporting } 42)\end{array}$ & $\begin{array}{l}\text { China } 287(60 \%) \\
\text { USA } 34 \\
\text { Vietnam } 20 \\
\text { Canada } 50\end{array}$ \\
\hline C. Korea & 52 million & 1092 & $\begin{array}{l}630(58 \%) \text { (toys } 322, \\
\quad \text { clothing } 87, \text { stationary } \\
54, \text { footwear } 42, \text { sporting } 32 \text { ) }\end{array}$ & $\begin{array}{l}\text { China } 420(67 \%) \\
\text { Vietnam } 13 \\
\text { Korea } 162\end{array}$ \\
\hline D. Japan & 126 million & 206 & $\begin{array}{l}20(10 \%) \text { (toys } 5 \\
\quad \text { clothing } 4)\end{array}$ & $\begin{array}{l}\text { China } 4 \\
\text { Japan } 1 \\
\text { Unknown } 15\end{array}$ \\
\hline E. UK & 68 million & 290 & $63(22 \%)($ toys 55$)$ & Unknown: 25 \\
\hline F. USA & 328 million & 745 & $\begin{array}{l}198(27 \%) \text { (clothing } 50, \\
\text { toys } 44, \text { furniture } 39)\end{array}$ & $\begin{array}{l}\text { China } 116(59 \%) \\
\text { Vietnam } 7 \\
\text { USA } 37\end{array}$ \\
\hline Total & 636 million & 4328 (of 10214 ) & 1685 (of 3792) & China 1014 \\
\hline
\end{tabular}

${ }^{a}$ Retrieved from https://data.worldbank.org/indicator/SP.POP.TOTL (accessed 9 Dec 2019).

${ }^{b}$ Recalls (including for "child" products, and by jurisdiction of origin) as of 9 December 2019. Retrieved from https://globalrecalls.oecd.org/\#/ (accessed 9 December 2019)

jurisdictions, the reports include (844) recalls for automobiles themselves, not just automotive accessories such as children's car seats.

It is also preferable to control for the possibility that more recalls are due to not only higher volumes but also varieties of products, as population size increases. ${ }^{5}$ Accordingly, comparing overall recalls (column 3 of Table 1) by population (column 2 of Table 1), the per capita rate for Australia (row A of Table 1) can be found to be broadly similar to the rate for Canada (row B of Table 1). However, it is higher than the per capita rate for Korea (row $\mathrm{C}$ of Table 1). That country has around the double the population of Australia but reports only around half as many recalls over 2015-2017 (1092 total or 364 annually, compared with 741 total or 247 annually for Australia). Recalls in Korea for 2018 (408) were somewhat higher than those for 2017 (328) and 2019 (356 through to 9 December 2019), and indeed to the annual recalls in 2015 (482) and 2016 (445) according to the separate Korean government website, so the 2018 data on the OECD Portal do not appear overly skewed by the "slime products" recalls. Importantly, the annual per capita recall rate for general consumer products is significantly lower for Korea than for Australia. Remarkably, the rates are very much lower for:

- The UK (row E of Table 1): almost three times the population of Australia, yet half the total of recalls (only 290 over 2017-2019);

\footnotetext{
${ }^{5}$ It is admittedly conceivable that the same products or types are found in all selected countries, even those with smaller populations (such as Australia). Yet, even then, countries with larger populations (like Korea) would generally have more supplies of each, generating more incidents or risk per product (type) and hence more recalls.
} 
- Japan (row D of Table 1): five times as populous, yet with only a third of Australia's recalls (206);

- The USA (row F of Table 1): 13 times as populous, yet with a similar number of recalls (745).

The OECD recalls data summarized in Table 1 (for 2017-2019) also complement the observation from the Infographic (OECD n.d.) that toys/games are among the most highly recalled product categories ("for 2016-2019"). Searching under the "child" tag (column 4 of Table 1), Australia reported 298 recalls (40\% of the total 741), of which 85 were for toys and games. Around two thirds of the recalled children's products were identified as from China. Similar patterns are found in Canada, although with somewhat higher proportions of recalled children's "clothing" as well as local (Canadian) manufacturing. Korea also reports about two thirds of recalled children's products as being from China, but with significant local manufacturing too. But they are much higher $(60 \%)$ as a proportion of all recalls, especially for toys/games but also significantly for stationary or office supplies. The per capita rate for (630) recalls children's products in Korea, with double the population, is similar to that for Australia - suggesting that the latter may have comparatively more product safety problems with other types of (non-children) products. However, again, Australia has much higher numbers and rates of recalls for children's products than the UK (63), Japan (20), and the USA (198), where they comprise only $10-27 \%$ of all recalled products.

Overall, these preliminary comparisons suggest that Australia is doing far worse than the latter three countries, generating risks and wasting resources for consumers, suppliers, and regulators through conducting many voluntary recalls. Australia compares somewhat better to Korea, but still has a significantly higher per capita recall rate and has a rate similar to that of Canada. However, there do remain limits to how much we can learn from comparing OECD recalls data, because it depends on four key considerations:

(i) Consumers or others complaining to the suppliers;

(ii) Suppliers then undertaking voluntary recalls;

(iii) Regulators noticing these recalls;

(iv) Regulators then reporting them (accurately) to the OECD Portal.

On the first point, complaints may be limited due to general culture and/or costs and other economic impediments. This especially true in developing countries, such as Vietnam (Nottage et al. 2019, pp. 163-164). Yet, even in developed countries like Australia, consumers often report not finding it worthwhile complaining to suppliers (see, e.g., Treasury 2016).

Secondly, even when faced with complaints indicating significant product safety issues, suppliers may not engage in recalls because of the costs and (at least perceived) adverse publicity involved. Suppliers can become more incentivized when problems with the products are anyway more widely publicized. This occurs nowadays sometimes even in developing countries, including through social media, as in Thailand (Nottage et al. 2019, pp. 165-167 and generally pp. 26-27), or through government initiatives such as in the USA from 2008, allowing anyone to upload complaints about product safety concerns (see SaferProducts.gov, favourably reviewed by the U.S. Government Accountability Office (GAO) (2013)). Suppliers should also be further incentivized to conduct voluntary recalls if there is access to justice for product liability (PL) claims, especially through a US-style opt-out class action system to efficiently aggregate even smaller claims-spreading now beyond Australia and Canada to 
many EU states (Nagy 2019). However, only the USA still records uniquely high levels of PL claims, due mostly to a combination of idiosyncratic features in its civil procedure and social security systems (Machnikowski 2016; Reimann 2003).

Another factor potentially impacting on voluntary recall rates could be the extent of mandatory safety standards for specific products, which are often focused on products for children because of their higher vulnerability. In January 2020, for example, there were 44 products subject to mandatory safety standards in Australia (of which around half were for children's products) (ACCC n.d.), compared with only 10 mandatory safety standards set for general consumer products in Japan (with only one for a child product) under its Consumer Product Safety Act. ${ }^{6}$ One hypothesis is that if there are more standards, there should be fewer recalls per capita as products put on the market should meet minimum mandatory safety standards. Yet this is not what we observe in Australia, compared with Japan, from the OECD data shown in Table 1. An alternative hypothesis is that if regulators do not enforce mandatory safety standards by adequately sanctioning suppliers, there may instead be more recalls conducted as regulators threaten sanctions for non-compliance, albeit belatedly after they or consumers notice problems with products, and/or retailers dealing with consumer complaints or conducting audits pressure their importers or other suppliers to withdraw non-compliant products. ${ }^{7}$ This phenomenon of comparatively high levels of recalls, combined with quite high numbers of mandatory safety standards, is found in fact for Australia in a study reported in Part 3 below based on a closer analysis of voluntary recall notifications.

In addition, if consumer affairs regulators can invoke a GSP (requiring all consumer products to be safe) and credibly do so in fact, we might expect fewer voluntary recalls because there are fewer unsafe products. Overall, at least in the long term, effective enforcement of various regulatory requirements, combined with the possibility of private law suits and/or influences from the media and corporate reputation, should incentivize suppliers to only put safe products into circulation in the first place. This would mean declining or low per capita rates of voluntary recalls. However, as sketched above, the disparate influences are difficult to determine just from comparing recall numbers.

Thirdly, another complication with OECD data is that even when voluntary recalls take place, national regulators need to become aware of them. This is easier when domestic law requires suppliers to report such recalls, as under 1986 amendments to Australia's Trade Practices Act (restated from 2010 as s. 128 of the ACL). Even then, the regulators may not collect reports effectively, as Australia's Productivity Commission found in its 2006 and 2008 reports (Productivity Commission 2006, 2008), which prompted the government to establish

\footnotetext{
${ }^{6}$ The sole child product is baby cots, which (along with three others out of the total 10) additionally requires third-party conformity assessment. See summaries by the Ministry of Economy Trade and Industry. Retrieved from https://www.meti.go.jp/policy/consumer/seian/shouan/act_outline.html (in Japanese) (accessed 5 May 2020 ). Similarly, see summaries by the Japan Quality Assurance Organization. Retrieved from https://www.jqa. jp/english/safety/service/mandatory/psc/ (accessed 20 January 2020). These mandatory standards are partly supplemented by a scheme for manufacturers to subject products for testing and insurance, praised by Ramseyer (1996). For a more sceptical appraisal of this scheme, and details on consumer product safety law and practice, see Nottage (2004).

${ }^{7}$ Anecdotally, especially the larger retailers in Australia (with significant quality assurance and complaints handling departments) do undertake audits and other responses that generate pressure on their suppliers to address non-compliant or otherwise risky products. But the policy question such a practice raises, which bolsters the argument for introducing a GSP extending also to products for which no specific mandatory safety standards have been set, is why such retailers do not better audit their suppliers' products before on-selling rather than (sometimes) afterwards.
} 
quite belatedly the www.productsafety.gov.au website. Alternatively, or (as in Australia since 2010) in addition, regulators can become aware of voluntary recalls if suppliers are required to report product safety-related accidents or incidents to them. Such mandatory reporting obligations provide a further incentive to recall products if there is a significant risk of harm, especially if the reports become public information so consumers can more readily become aware and concerned about safety risks. However, one difficulty is that the scope of mandatory reporting requirements can be quite limited. For example, Australia only requires reports of deaths or injuries or rapid-onset illness prompting treatment by doctors or nurses. By contrast, since 2006 amendments to the Consumer Product Safety Act and related regulations, Japan also requires reporting if there are product-related fires or carbon monoxide emissions even if no one was actually harmed. The EU (since 2001) and (since 2011) Canada similarly require reporting of such "near misses," and indeed any other serious product-related health risks. All these jurisdictions also vary in terms of statutory confidentiality obligations and regulatory practices concerning public disclosure of mandatory accident reports, with Australia being the most restrictive (Nottage 2011).

Elsewhere in Asia, there are few legislative requirements for suppliers to report their voluntary recalls, or accidents (let alone near-misses or other incidents), to general consumer product safety regulators. An exception among ASEAN states is Vietnam, where the 2010 Law on Protection of Consumers' Rights requires suppliers to conduct and publicize recalls if aware that their product has a defect. However, suppliers might insist that the products are not defective and are therefore not required to be recalled through the prescribed channels (see, e.g., discussing a Canon camera case, Nottage and Paterson 2019). Of the (only) 208 recalls reported from ASEAN states for the OECD Recalls Portal, out of over 25000 reported as of December 2017, there were only 38 recalls from Vietnam and indeed 27 of those were for automobiles.

Fourthly, even if reports come in to national regulators, they need to be accurately and comprehensively transmitted to the OECD Recalls Portal. As mentioned in the Introduction ASEAN states did not contribute data until after recommendation by consultants in late 2014 that its "product alerts" website data (ACCP 2020) should be added to the OECD Portal. The latter now contains recall notifications from ASEAN states beginning from 1 July 2013: Kanebo skinwhitening cosmetics notified by Vietnam (in a field subjected to regional harmonization deriving from the EU cosmetics regime; Nottage et al. 2019, Chapter 3, Appendix B; Zakaria 2015) and Honda airbags notified by Malaysia. Assembling and passing on data to the OECD is a particular problem for smaller and/or developing countries. For example, there are no recalls notified to the OECD from Laos, Cambodia (which only enacted a comprehensive consumer law in 2019: Tilleke and Gibbins 2019), and Myanmar (which enacted one in 2019 to amend that of 2014: ZICO 2019; Nottage et al. 2019, pp. 134-135 and 143-146). Neither new law, let alone the older and quite general Consumer Protection Act in Laos, requires suppliers to notify consumer affairs regulators about voluntary recalls or product-related accidents or serious health risks. Accordingly, we cannot expect much input into the OECD Portal from these least-developed ASEAN states. Even for larger economies, there are still comparatively few recall notifications reported. The 208 recalls notified as of December 2019 were from Indonesia (47), Singapore (43), Vietnam (38), the Philippines (38), Thailand (21), Brunei (13), and Malaysia (10). Of this total, 84 were "automotive," almost all vehicles (plus some tyres recalled in Vietnam). Details from ASEAN states are also quite sketchy, and the reports are not directly cross-linked to recall notifications received from other jurisdictions.

For these four sets of reasons, policy-makers must be cautious in interpreting the OECD Recalls Portal data. For example, Canada may be reporting per capita voluntary recall rates similar to those of Australia, despite having adopted a GSP from 2011, because the Canada 
Consumer Product Safety Law 2010 established anyway a wider scope of reportable productrelated accidents and health risks, compared with the scope of mandatory accident reporting under s. 132 of the Australian Consumer Law in effect from 2011 (Nottage 2011). Nonetheless, it remains striking and concerning that Australia's recall rates have remained consistently high compared with those of Korea and especially Japan, the UK, and the USA.

\section{Problems with Australia's Current Regime: Socio-economic and Legal}

The preliminary comparison of Australian recall data, notified through the OECD Recalls Portal, does bolster the Consultation RIS's summary of the three key sets of problems that the Australian government suggests may afflict the current product safety law regime under the ACL (and other legislation):

- Many unsafe products entering the Australian market and causing harm;

- Slow (mostly post-market) regulatory responses;

- Uncertainty and lack of knowledge about the regime.

In their submission on the Consultation RIS, urging Australia to adopt "Option 6" to add a GSP to the ACL in order to promote "cultural shift" in its product safety system, two major consumer NGOs (Choice and the Consumer Action Law Centre) highlighted as follows how annual voluntary recalls have continued to grow since $1998^{8}$ :

That joint submission (Choice 2019a, p. 7) also pointed to new ACCC data showing "that there are 6.6 million individual products currently under voluntary recall." It is also argued that only about half of recalled products are returned to the retailer and that in October 2019, the ACCC reported that there were about 1.7 million recalled products still in people's homes (not including automobiles) (CHOICE 2019b). The joint submission went on to provide several case studies of product safety failures or risks, including bassinets and baby pods for which Australia currently has no specific mandatory (or indeed voluntary) standards (CHOICE 2019a, pp. 11-14).

As a further illustration of consumer product safety problems in Australia, co-researchers in an ARC-funded research project focusing on child product safety (compared especially with the USA) reported in a recent peer-reviewed article that for 2011-2017 voluntary recalls (Niven et al. 2019, emphasis added):

Australian child-related recalls increasing by $88 \%$ over 7 years, while US child-related recalls decreased by $21 \%$ over the same period. This result is unexpected given the US consumer market is 18 times larger than the Australian consumer market and suggests a need to change the reactive approach to product safety in Australia.

Niven et al. also note ${ }^{9}$ that voluntary recalls across all consumer products have been trending upwards in Australia as follows over 1995-2019, according to the Product Safety Australia

\footnotetext{
${ }^{8}$ Adapted from the Submission by CHOICE (2019a, p. 6), which compiled a figure from data available from Australia Competition and Consumer Commission's Product Safety website. This figure adds total product recalls for 2019 based on the data available as of 16 February 2020. Retrieved from www.productsafety.gov.au (accessed 16 February 2020).

${ }^{9}$ Private correspondence from Niven et al., for 1998-2018 data, confirmed and supplemented by recall numbers for other years retrieved from https://www.productsafety.gov.au/recalls.
} 


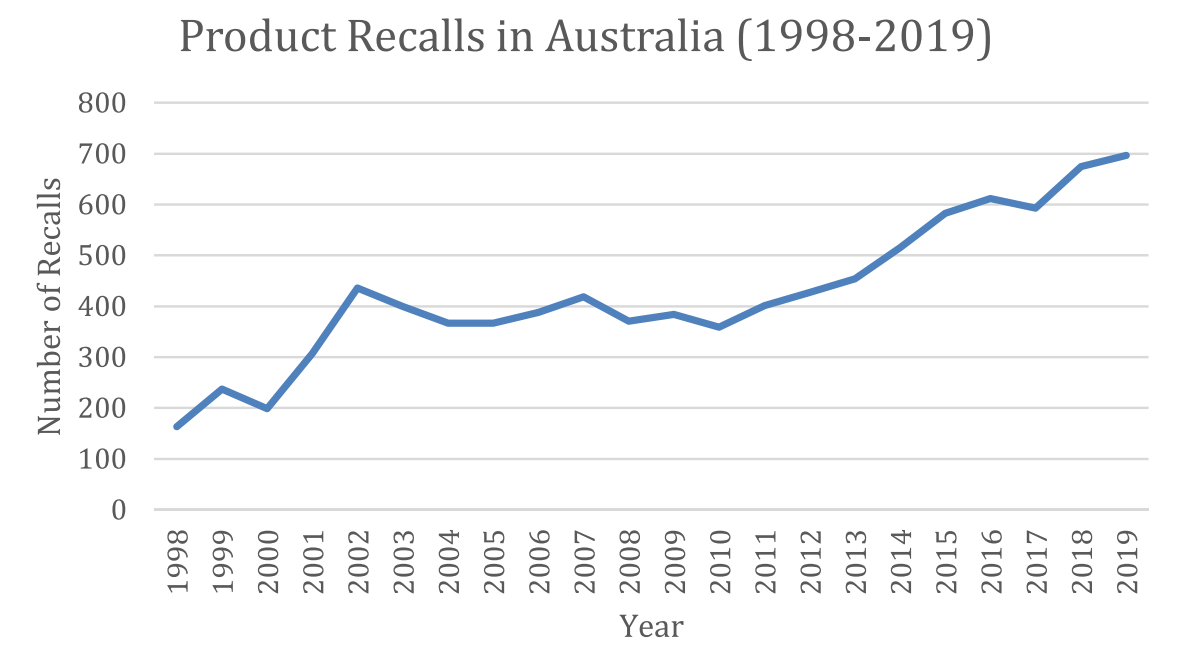

Fig. 1 Product recalls in Australia (1998-2019) (data as of 16 February 2020, retrieved from www.productsafety.gov.au (accessed 16 February 2020))

website, mirroring the depiction in Figure 1 from the joint submission above:

$\begin{array}{llll}2019: 697 & 2012: 427 & 2006: 388 & 2000: 199 \\ 2018: 675 & 2011: 401 & 2005: 367 & 1999: 237 \\ 2017: 593 & 2010: 359 & 2004: 367 & 1998: 163 \\ 2016: 612 & 2009: 384 & 2003: 400 & 1997: 51 \\ 2015: 583 & 2008: 371 & 2002: 436 & 1996: 88 \\ 2014: 515 & 2007: 419 & 2001: 307 & 1995: 64\end{array}$

2013: 455

This shows three significant steps up in annual recalls (including automobiles): from 1997 to 1998 onwards, 2001 to 2002 onwards, and since around 2012. The last increase seems particularly noteworthy. It arguably relates to the dramatic growth of online trading and shopping in Australia in recent years, which is only set to increase further (see, e.g., Transdirect 2020; WebAlive 2019), and presents global challenges for consumer protection law (Durovic 2019; Howells 2020). Burgeoning e-commerce expands the influx of cheaper but often lower-quality goods imported into Australia from abroad, including from the PRC, which is developing strong interest in harmonizing consumer law (Wei 2020), as noted in the RIS and in the literature or data from other jurisdictions. For example, Treasury (2019a, p. 14) remarked that an OECD Report in 2016 "found that with respect to products that do not meet voluntary or mandatory safety standards, the level of non-compliance was twice as high for goods sold online overseas ( 88 per cent of inspected products) compared to those sold online domestically (44 per cent of inspected of products)."

It is unlikely that the increase in annual voluntary recalls from 2012 can be explained primarily instead by significantly better education and awareness, given the lack of clarity and understanding about Australia's current regime (noted in the Consultation RIS and elsewhere), although more publicity and guidance for firms was generated around the time of the ACL reforms enacted already around 2010. Nor is the step-up in recall notifications since 2012 likely to be due mainly to the new duty imposed on suppliers under those reforms, to report 
serious product-related accidents to regulators, given that the duty was already enacted in 2010 and had a comparatively narrow scope (as mentioned in Part 3 below). The growth in annual recalls since 2012 also does not seem to be due to significantly much better enforcement, ${ }^{10}$ as resources for the ACCC and other regulators regarding product safety do not seem to have increased significantly since 2012, and there have been only a few cases reported of successful ACL enforcement action. ${ }^{11}$ Nor are growing annual recalls likely to have been due to any significant increase in mandatory safety standards, as only a few have been added in recent years, or in public safety warnings. As the Consultation RIS notes, there have only been 10 public warnings since 2013, under ACL s. 223, and some later triggered further regulatory responses anyway such as for ethanol fireplaces, Takata airbags, and hoverboards (Treasury 2019a, especially pp. 19-24).

Rather, the attitude among (perhaps especially smaller) suppliers seems to be increasing: "let's just import or supply the product, see what happens; if we get reports of injuries or complaints, and especially if the regulators query us, let's issue a voluntary recall and hope that solves the problem." A similar attitude can be inferred from a July 2018 "White Paper" report from a private consultancy form, run by an experienced former ACCC official (Greatorex 2018). The attitude can also be inferred by another surprising finding from the recent publication by Niven et al. (2019, emphasis added):

\begin{abstract}
the majority of Australian child-related recalled products failed to comply with mandatory safety requirements. While various factors might contribute to the lower level of non-compliance reporting in US child-related recalls, it is worth noting that the USA introduced conformity certification reforms in 2008 to address safety issues with imported consumer products. A manufacturer of a children's product imported into the USA must issue a certificate stating that the product complies with applicable US regulatory safety requirements. The certificate must be based on third-party conformity testing and accompany the product or shipment. Australia does not have a similar conformity certification requirement, placing a significant burden on regulators to identify, test and remove non-compliant products from the Australian market. The high level of product non-compliance identified in the Australian recalls points to a need for Australia to consider additional premarket procedures, such as a conformity certification requirement for children's products of types that are subject to mandatory safety standards.
\end{abstract}

Especially if this US-style requirement is not added to the ACL regime, an EU-style GSP should be added so that importers and suppliers assess and monitor product risks beforehand, rather than after injuries or complaints occur. The GSP should lead to a more pro-active approach to safety risk assessment taken by suppliers, before putting goods on the market. This can explain why voluntary recall rates are far less frequent in the UK compared with those in

\footnotetext{
${ }^{10}$ A recent news article suggests that a decrease in annual recalls in the USA since 2017 may be due to less robust leadership (by a Republican) and therefore enforcement (Frankel 2020). However, that also seems overly simplistic given the observed longer-term decline in annual recalls from 2008 (when problems with toys especially from the PRC were at a peak). In conjunction with new powers and resources for regulators, US suppliers seem to have taken consumer product safety issues even more seriously since then, trading in safer products and therefore having to conduct fewer recalls.

${ }^{11}$ In 2019, the ACCC's product safety division completed a split into risk assessment (e.g., investigations) and risk management (e.g., monitoring of recalls), aimed to greater efficiencies, but overall staffing does not seem to have increased.
} 
Australia, as illustrated in the OECD Recall Portal summary table in Part 2 above, and earlier pointed out by Choice during the ACL Review process over 2015-2017. ${ }^{12}$

\title{
Limitations in Existing ACL Provisions on Recalls and Accident Reporting
}

Another problem impacting on whether and how to introduce a GSP, highlighted by Niven et al. (2019) but not the Consultation RIS, is the comparative lack of specificity required in Australia regarding the content of recall notices (emphasis added):

\begin{abstract}
First, the inclusion of de-identified injury information is not a requirement for Australian recalls, and the absence of data restricts the ability to analyse injuries associated with recalls. More fundamentally, the lack of injury information in a recall notice impacts on the ability to effectively communicate the product hazard to consumers. Second, country of origin data were not available in the Product Safety Australia published recall notices and were, instead, extracted from Australian recalls published on the OECD global recall portal. The reason for this irregularity is unclear, and the inclusion of country of origin data is valuable to identify leading source countries for recalled products, which can then inform cross-border safety communications and surveillance. Lastly, Australian recalls could be improved by requiring information on the number of product units being recalled to more effectively communicate the extent of public exposure to the hazard.
\end{abstract}

These criticisms echo concerns raised during the ACL Review process (but not adopted in the CAANZ Final Report) by Choice and others providing submissions, calling also for suppliers to have to periodically and publically disclose progress in recalls.

As mentioned in Part 2 above as a complicating factor when assessing the OECD Recalls Portal data, a problem with the ACL regime is that the scope of mandatory accident reports introduced (belatedly) from 2011 is comparatively narrow (not extending to all serious health risks). Another is that a late addition to the ACL (s. 132A) means that in Australia, reports are not disclosed to the public, unlike the narrower subset of voluntary recalls, which have to be notified to the regulators and then are made public (Nottage 2011). Penalties for not making mandatory accident reports are also low, and increases were not enacted in recent ACL amendment despite the 2017 ACL Review recommendation (mentioned in Part 1 above), perhaps because of federal guidelines (Attorney-General's Department 2011). Each infringement anyway must be proved separately. This likely explains why the ACCC has not brought many actions and even where it has sought larger aggregate amounts by adding arguments about misleading conduct, as in claims against Woolworths and Thermomix, mentioned further below and in the Consultation RIS (Treasury 2019a, p. 25).

Such limitations around mandatory accident reporting obligations also contribute to suppliers arguably not taking product safety as seriously as in other jurisdictions with broader reporting requirements. Since the ACL Review did not adopt Submissions by myself and others to broaden them in these respects (see, e.g., Nottage 2016; Nottage and Niven 2017), and a 2017 Productivity Report recommendation to set up a public complaints or product safety incident database seems to be making very slow progress (Productivity Commission 2017), this further bolsters the case for introducing an EU-style GSP.

\footnotetext{
${ }^{12}$ As tabulated already in an earlier ACL Review submission by CHOICE (2016, pp. 38-39), over 2013-2015 voluntary recalls in the UK were half the numbers annually as in Australia, despite the UK population (and consumer market place) being much larger.
} 


\section{Deficiencies in Coordinating General and Sector-Specific Regulation}

Another aspect that the Consultation RIS downplays is the problem of coordination between the general consumer regulators (already dispersed among the ACCC and state/territory regulators) and sectorspecific regulators. There is some mention of the Therapeutic Goods Administration and Food Standards Authority Australia and New Zealand, as well as the transport department (Treasury 2019a, p. 63), plus an acknowledgement that the Takata airbag recall remains very problematic (with only $80 \%$ recalled) (Treasury 2019a, p. 21). A newspaper editorial of 7 October 2019 called this a disgrace and asks why registration was not being cancelled for 20000 vehicles recently warned by the government to be critical (out of over 400000 vehicles still to be fixed) or why their resale was not being banned (The Canberra Times 2019; see also Consumers' Federation of Australia 2019). Interestingly, the Korean government banned BMW vehicles recalled for other reasons from being driven, underpinned by criminal penalties on drivers. This prompted BMW to provide free replacement vehicles to those drivers while it completed recalls and remediation of their unsafe vehicles (DW2018).

Even without such reforms to Australia's laws on recalls, its regulators could already seek sanctions against car companies locally for poor progress in completing recalls of cars with dangerous Takata airbags. Because amendments to motor vehicles legislation, extending recall powers (and sanctions) to the transport regulator, have not been enacted-and even when enacted, will not take effect until 2021-only the ACCC can seek sanctions to incentivize suppliers to complete airbag-related recalls. Meanwhile, hearings began in October 2019 for a coronial inquiry in New South Wales into the fatal accident in July 2017 of a Honda driver, caused by a defective Takata airbag that had not been replaced. ${ }^{13}$ The coronial report can be expected to examine the effectiveness of recall notices and practices and the interaction between sector-specific (transport) and general consumer affairs regulators. It may even recommend adding a GSP to the ACL, like the 2019 report of a coronial inquiry in Victoria into a fatality from a child ingesting a button battery (as cited in Treasury 2019a, p. 13).

The other large problem area in Australia has been the interaction between the consumer regulators and those dealing with electrical products (exemplified by problems with recalls involving Infinity cabling in homes, with follow-up apparently now being provided by the NSW OFT rather than ACCC, and Samsung washing machines). A more contemporary example may be e-vaping (Grieve 2019a, b), where Australia's consumer regulators-despite being experts in safety, marketing, and consumer behaviour generally-have not been evident in the current public debate. ${ }^{14}$ Again, unless consumer regulators decide to take a more active role in monitoring and intervening in consumer product markets where there is also a sectoral regime and regulator, suppliers need to be better incentivized to supply safe products by the introduction of a GSP.

At present, as well as resource constraints (apparently only around 60 staff for product safety activities out of over 1,000), the ACCC and other consumer regulators may feel constrained by the Government's current "Statement of Expectations - ACCC," especially where there could be "duplication" of supervisory activities of other regulators. ${ }^{15}$ But if that

\footnotetext{
${ }^{13}$ See, e.g., Mitchell 2019. Hearings were expected to resume in March 2020, whereupon witness statements and other evidence may become publically available, but the COVID-19 pandemic has affected this timetable. However, the ACCC (2017) did successfully obtain penalties in 2017 against e-cigarette suppliers that misleadingly stated they contained no harmful chemicals found in ordinary cigarettes.

${ }^{14}$ However, the ACCC (2017) did successfully obtain penalties in 2017 against e-cigarette suppliers that misleadingly stated they contained no harmful chemicals found in ordinary cigarettes.

${ }^{15}$ Compare the ACCC's current Response to the Government. Retrieved from https://treasury.gov. $\mathrm{au} /$ sites/default/files/2019-03/ACCC_Statement_of_Intent.pdf (accessed 5 May 2020).
} 
cannot be interpreted more liberally (and resources devoted to the ACCC) to achieve more "robust and effective" partnerships, then the Statement of Expectations should be revised by the Government. After all, not only do consumer regulators have general technical expertise in safety issues, but they also have more general expertise about consumer and supplier behaviour (including marketing/impacts) compared with many other sectoral regulators.

\section{Private Law Mechanisms: Diminishing Impact}

A final aspect not emphasized in the Consultation RIS is that private law mechanisms potentially incentivizing suppliers do not seem to be playing much role. Despite significant media-reported product failures and the observed increase in voluntary recalls, there is very little case law on the ACL's (EU-style) strict liability provisions or the (NZ-style) consumer guarantee of "acceptable quality" including specifically safety. What case law there is tends to be in tribunals, with conflicting decisions, and/or with little precedential value (Paterson 2016, pp. 220-223). The ACCC has not initiated representative actions to obtain determinations. Rather, in December 2019, it and other consumer regulators issued some guidance including simple examples. Meanwhile, Australian class action law firms (Morabito 2017) continue to focus on investor cases, not product liability claims any more, due to fewer problems establishing causation or loss among larger groups of victims.

The Consultation RIS does rightly highlight the large penalty ordered in ACCC $v$ Thermomix (2018), for misleadingly not disclosing safety issues (see Treasury 2019a, p. 25). Yet there the company conceded liability (like in the earlier ACCC $v$ Woolworths (2016) judgement, summarized in ACCC (2016)). Further, if injured consumers had brought suit, they would have to claim under different ACL causes of action (excluding misleading conduct, as it is no longer claimable for personal injury following Australia's nationwide tort law reforms; Kellam and Nottage 2007). Once again, this diminished capacity for private law to incentivize suppliers bolsters the case for stronger interventions through public regulation.

\section{Overall Economic Costs and Benefits}

For the Consultation RIS, the ACCC provided an Appendix estimating the annual cost to the Australian economy from unfair products, killing 780 Australians and injuring 52000 each year, to be "at least $\$ 5$ billion and ... likely ... much higher," compared with consumer goods market of $\$ 173$ billion in 2018-2019 (Treasury 2019a, p. 18). But the related Appendix does not explain where the data comes from re annual deaths or disability. Our ARC Discovery Project research highlights the very disparate and poor data collected in and from hospitals in Australia, compared say with the USA where the federal consumer regulator sends staff to large hospitals and coordinates much better information-gathering. It is also unclear whether the ACCC calculations include deaths and serious injuries from products covered by sectoral regulators, like vehicles (the Appendix does separate out quad bikes, which remain a high-profile problem in Australia; see, e.g., Grieve 2019b). The calculations also may only count an economic loss from a disability starting from 1 year, whereas many consumer product safety problems affect victims for shorter periods (but collectively putting significant drain on the economy). Such incidents (see examples in CHOICE 2019a, p. 5) are also far less likely to be reported.

Anyway, even a conservatively estimated economic loss of $\$ 5$ billion is a very significant ground for regulatory intervention. It should be recalled that the 2010 ACL re-harmonization nationwide, including "trading up" to higher standards in some respects (e.g., adding the mandatory accident 
reporting requirements), was bolstered by the Productivity Commission's 2008 Inquiry Report into consumer policy estimating that its "reform package could provide a net gain to the community of between $\$ 1.5$ billion and $\$ 4.5$ billion a year" (Productivity Commission 2008).

Also deserving more explicit acknowledgement are the economic gains in harmonizing and "trading up" to higher product safety regulatory standards, through having laws aligned with those of major trading partners, and educating accordingly our suppliers (including actual and potential exporters) and legal or other professional advisors. For the GSP in Option 6, the Consultation RIS emphasizes the UK General Product Safety Regulations 2005 (Treasury 2019a, p. 41). However, as mentioned in Part 1 above, the UK in fact introduced earlier a form of GSP through s. 10 of the Consumer Protection Act 1987 (albeit requiring goods to be "reasonably safe"). In turn, that formulation was enacted in the context of a GSP enacted in 1983 consumer law in France and in an earlier Appliances Safety Act in Germany, as well as discussions on product safety that eventually generated the 1992 EU Product Safety Directive. ${ }^{16}$ The 1987 UK Act then influenced the introduction of a GSP in Malaysia through s. 21 of the Consumer Protection Act 1999, and in Hong Kong through s. 4 of the Consumer Goods Safety Ordinance, as well as throughout the EU due to the 1992 General Product Safety Directive. The latter in turn impacted on Macau and later Canada and partly Singapore. Accordingly, there are extensive precedents and experiences available for regulators as well as suppliers in Australia by sticking to the tried and tested EU-style GSP, as an amendment to the ACL regime.

\section{Conclusions}

As shown in Part 2 by a preliminary analysis mainly of 2017-2019 data from the OECD Global Recalls Portal, Australia maintains persistently high levels of voluntary recall rates per capita, compared with several other major jurisdictions especially in the Asia-Pacific region with broadly comparable economies and consumer product safety law regimes. Part 3 showed how annual recalls have grown in Australia especially from 2012. Part of this increase might be due to more awareness among suppliers (and the wider community) about product safety risks, and/or more efforts from Australian regulators around the time of the ACL reforms, but those were mostly completed around 2010. A more important contributing factor is arguably the growth of e-commerce, resulting in more imports (and importers) of cheap but less safe products, which end up being recalled after problems are highlighted. A closer analysis of the types of recalls, especially for children's products, highlights a further disturbing tendency: Many products are recalled having not complied with mandatory safety standards set under the ACL, yet few sanctions from regulators have been reported. Combined with various other challenges facing Australia's regulatory regime, outlined in Part 3, it does seem to be time for significant reforms to the ACL. In particular, a cultural shift is needed so that all suppliers take a more pro-active approach to assessing safety accurately, before importing or otherwise putting consumer products onto the market.

In terms of the Consultation RIS released in late 2019, the best way to achieve this would be for Australia to add an EU-style GSP to the ACL, as set out as Option 6. It is conceivable that suppliers might nonetheless persist in a reactive and indeed somewhat cavalier approach, evident for example

\footnotetext{
${ }^{16}$ See, e.g., in a special issue mainly comprising reprinted English translations of early contributions to the European reform debates: (Bruggermeier et al. 2010), especially 140-144 (France), 171-173 (UK), 191-195 (Germany).
} 
from the significant proportions of voluntary recalls for products (often children's products) for which there are already specific mandatory safety standards. Yet, by adding a GSP, suppliers (and their professional advisors) would need to adopt a new mindset. They would have to assume that ex ante safety standards exist, enforced by public authorities (rather than mainly ex post regulatory interventions, or quite limited exposure in practice to compensation claims brought by consumers proving harm caused by unsafe products). They would therefore be encouraged to adopt a more proactive approach to assessing product safety before putting products onto the market.

In addition, as mentioned below, Australian law reformers could adopt the (EU-style GSP) Option 6 in combination with (but not instead of) the reform Options 3 and 4 in particular, and even add a novel "product safety substantiation order" power for the consumer affairs regulators. Options 1 (no change) and 2 (better education) are inadequate, given the demonstrated extent of unsafe products in Australia, as well as the uncertainties and gaps in the current ACL regime, although better education about legal obligations and reforms is always welcome.

Compared with a new GSP, less impact would be achieved through reform Option 5, which proposes instead to "impose a new duty on traders to take reasonable steps to ensure products placed on the market are not 'unsafe', consistent with existing ACL principles ... [and] would operate in a similar way to existing work health and safety laws that require businesses to do what is reasonably practical" (Treasury 2019a, p. 37). This proposal has already attracted the support of one experienced commentator (and former ACCC official), but seemingly more out of concern that the GSP Option 6 will have too much impact on the business sector (Greatorex 2019). Yet Option 5 lacks the advantage of a regime harmonized with that found increasingly abroad (in the EU and beyond), because it is a uniquely Australian innovation. Furthermore, Option 5 appears conceptually incoherent and confusing because it takes as the initial test for suppliers the "safety defect" definition in s. 9 of the ACL (designed for strict product liability), yet combines that with a defence based on taking reasonable steps. It will likely generate significant uncertainties for suppliers, regulators, and courts to try to square that circle in a consumer product safety context.

In explaining Option 5, the Consultation RIS mentions that the "reasonable steps" defence would allow the supplier's individual circumstances to be assessed: "For example, what is considered reasonable for a manufacturer may not be reasonable for a retailer, given that their level of knowledge and control is likely to vary substantially." Yet, for similar reasons, the EU's General Product Safety Directive already builds in some differentiation between the responsibilities of "producers" compared with "distributors." Other non-EU countries that add a GSP also put less onus on non-manufacturers. ${ }^{17}$ Some jurisdictions also have a carefully worded defence of due diligence. ${ }^{18}$ Australian legislators can consider these or other defences even if they decide to adopt an EU-style GSP provision for the ACL.

The Consultation RIS sets out Option 4 as another possible reform measure, but it too has problems. Regulators would be given a new "safety intervention power" allowing them to address "conduct that has caused, or is likely to cause, 'significant detriment' to consumers, without having to obtain ministerial approval or establish a breach of the ACL in court" (Treasury 2019a, p. 34). This would be another quite uniquely Australian innovation, inspired

\footnotetext{
${ }^{17}$ For example, Malaysia's Consumer Protection Act 1999 s. 22 adds a defence only for product suppliers who are not manufacturers based on no knowledge or reasonable means of knowing that the products failed to comply with the s. 21 GSP. A similar defence for retailers is found in s. 22(2)(b) of the Hong Kong Consumer Goods Safety Ordinance 1995, transplanted from s. 10(4)(b) of the original Consumer Protection Act 1987 in the UK. Compare respectively Articles 5(1) and ("due care") 5(2), and Preamble Recitals 19 and 20.

${ }^{18}$ An example is s. 39 of the UK Act, transplanted into s. 24 of the Hong Kong Ordinance of 1995, but not found in Malaysia's Act of 1999.
} 
by recent amendments to the ASIC Act (Hilder et al. 2019) in response to calls for regulators to be able to ban detrimental financial services. (Nottage and Kozuka (2012) provide an earlier recommendation along these lines, i.e., drawing from consumer product safety law to improve financial services regulation, rather than vice versa as now proposed in Option 4.) Yet the proposed power's differences with existing ACL product ban powers are hard to assess, and so would likely lead to significant uncertainties and therefore costs. A more clearly reformulated power could be introduced, but that would still put the burden on the regulator to act, rather than more directly on the supplier to assess their own product risks as with an EU-style GSP. Accordingly, Option 4 should be additional to introducing Option 6 to the ACL, not instead of it.

Option 3 is even more inadequate on its own because it is still a completely reactive postmarket intervention power. It is also quite complex. Option 3 seems mainly to build on the $A C C C v$ Woolworths (2016) case where the supermarket agreed with the regulator's claim that it was a misleading conduct to continue displaying and supplying goods that it knew (from consumer reports) were causing accidents, although the supermarket did contest the fine amounts. Option 3 proposes first to introduce:

- A "prohibition of continuing to supply unsafe products," for regulators to apply if the product was unsafe, suppliers knew this, yet continued to supply

- A "notice of risk" issued to particular suppliers (unlike bans under the ACL applying to all products with those features, usually after going through a RIS consultation process) and possibly confidentially (unlike a public warning as also allowed already by the ACL) that could help demonstrate that the supplier knew that the (regulator considered that the) product had a "safety defect" as defined under ACL s. 9 (see Treasury 2019a, pp. 31-32).

Despite its complexity, a version of this Option 3 could be useful to implement together with the pre-market GSP set out in Option 6 (alongside perhaps also Option 4).

Lastly, when adding Options 3 and/or 4 to Option 6, the ACL regime could also be made more pro-active by adding a new power for regulators to have suppliers show cause as to how they believe their products are in fact safe. In other words, add a "product safety substantiation order" power for regulators, like that usefully added in 2010 as s. 219 of the ACL to address potentially misleading conduct. With Option 6 based on the EU model, being able to show cause is already implicit because suppliers would normally have to keep and disclose if necessary a risk assessment file, to establish compliance with a GSP.

\section{References}

ASEAN Committee on Consumer Protection (ACCP). (2020). ASEAN product alerts. Retrieved from https://aseanconsumer.org/product-alert. Accessed 5 May 2020.

Attorney-General's Department. (2011). A guide to framing Commonwealth offences, infringement notices and enforcement powers. Retrieved from https://www.ag.gov.au/Publications/ Pages/GuidetoFramingCommonwealthOffencesInfringementNoticesandEnforcementPowers.aspx. Accessed 5 May 2020.

Australian Competition and Consumer Commission (ACCC). (n.d.). Mandatory standards. Product Safety Australia. Retrieved from https://www.productsafety.gov.au/product-safety-laws/safety-standardsbans/mandatory-standards. Accessed 5 May 2020.

Australian Competition and Consumer Commission (ACCC). (2016). Woolworths mislead consumers over product safety hazards - Ordered to pay over $\$ 3$ million in penalties. Retrieved from https://www.accc.gov. 
au/media-release/woolworths-misled-consumers-over-product-safety-hazards-\%E2\%80\%93-ordered-topay-over-3-million-in-penalties. Accessed 5 May 2020.

Australian Competition and Consumer Commission (ACCC). (2017). E-cigarette companies to pay penalties. Retrieved from https://www.accc.gov.au/media-release/e-cigarette-companies-to-pay-penalties. Accessed 5 May 2020.

Australian Trade and Investment Commission. (n.d.). Australia's trade and investment linked to Asia's powerhouse economies. Retrieved from https://www.austrade.gov.au/news/economic-analysis/australia-s-tradeand-investment-linked-to-asia-s-powerhouse-economies. Accessed 5 May 2020.

Bruggemeier, G., \& Falke, J., Joeges, C., Micklitz, H.-W. (2010). Examples of product safety legislation. Hanse Law. Review, 6, 135.

CHOICE. (2019a). CHOICE and CALC submission to Treasury on their review of the product safety system. Policy submission. Retrieved from https://www.choice.com.au/consumer-advocacy/policysubmissions20170112t141841. Accessed 5 May 2020.

CHOICE. (2019b). CHOICE renews call for stronger product safety laws. Retrieved from https://www.choice. com.au/shopping/consumer-rights-and-advice/your-rights/articles/choice-product-safety-submission-totreasury. Accessed 5 May 2020.

CHOICE. (2016). Issues paper for the review of the Australian Consumer Law. Retrieved from https://www. choice.com.au/consumer-advocacy/policy-submissions20170112t141841. Accessed 5 May 2020.

Consumers' Federation of Australia (2019). Consumers warned of new airbag safety risk. Retrieved from http://consumersfederation.org.au/consumers-warned-of-new-airbag-safety-risk/. Accessed 5 May 2020.

Council of Australian Governments. (2009). Intergovernmental agreement for the Australian Consumer Law. Retrieved from https:/consumerlaw.gov.au/sites/consumer/files/2015/06/acl iga.pdf. Accessed 5 May 2020.

Consumer Affairs Australia and New Zealand. (2017). Australian Consumer Law review: Final report. Australian Consumer Law. Retrieved from https:/consumerlaw.gov.au/sites/consumer/files/2017/04/ACL_Review_ Final_Report.pdf. Accessed 5 May 2020.

Consumer Affairs Australia and New Zealand. (2019). Guidance on the consumer guarantee as to acceptable quality and "safe". Retrieved from https:/consumerlaw.gov.au/consumers-and-acl/articles/guidancebusinesses-meanings-safe-and-durable-consumer-guarantees Accessed 5 May 2020.

Department of Foreign Affairs and Trade. (n.d.). Australia's free trade agreements (FTAs). Retrieved from https://dfat.gov.au/trade/agreements/pages/trade-agreements.aspx. Accessed 5 May 2020.

Durovic, M. (2019). International consumer law: What is it all about? Journal of Consumer Policy, 42, 1-19.

DW. (2018). South Korea bans recalled BMWs over fire fears. Retrieved from https://www.dw.com/en/southkorea-bans-recalled-bmws-over-fire-fears/a-45072421. Accessed 5 May 2020.

Frankel, T. C. (2020). Product recalls under Trump fall to lowest level in 16 years, but new signs emerge of a tougher regulator. The Washington Post. Retrieved from https://www.washingtonpost.com/business/2020 /01/13/product-recalls-under-trump-fall-lowest-level-16-years-new-signs-emerge-tougher-regulator/. Accessed 5 May 2020.

Greatorex, G. (2018). Consumer product safety in Australia: Challenges for practitioners and business managers - White paper. Product Safety Solutions. Retrieved from https://productsafetysolutions. com.au/product-safety-paradigm-shift/. Accessed 5 May 2020.

Greatorex, G. (2019). New product safety laws being considered. Product Safety Solutions. Retrieved from https://productsafetysolutions.com.au/new-product-safety-laws-being-considered/. Accessed 5 May 2020.

Grieve, C. (2019a). What is vaping and is it bad for you?. The Sydney Morning Herald. Retrieved from https:/www.smh.com.au/national/what-is-vaping-and-is-it-bad-for-you-20190926-p52v81.html. Accessed 5 May 2020.

Grieve, C. (2019b). 'Toxic mix': New quad bike rules overlook age restrictions. The Sydney Morning Herald. Retrieved from https://www.smh.com.au/national/toxic-mix-new-quad-bike-rules-overlook-age-restrictions20191010-p52zfb.html. Accessed 5 May 2020.

Hilder, K., Standen, M., \& Lockhart, I. (2019). ASIC is "ready and willing" to use its new product intervention powers. Lexology. Retrieved from https://www.lexology.com/library/detail.aspx?g=aff2f3ca-d367-46a08699-85a9c1290d6a. Accessed 5 May 2020.

Howells, G. (2020). Protecting consumer protection values in the fourth industrial revolution. Journal of Consumer Policy, 43, 1-31.

Kellam, J., \& Nottage, L. (2007). Happy 15th birthday, TPA part VA! Australia's product liability morass. Competition and Consumer Law Journal, 15, 26.

Lee, T. (2018). Slime-based toys recalled by govt over hazardous substances. The Korea Herald. Retrieved from http://www.koreaherald.com/view.php?ud=20181220000766. Accessed 5 May 2020.

Machnikowski, P. ed. (2016). European product liability: An analysis of the state of the art in the era of new technologies Intersentia. Cambridge: Intersentia. 
Mitchell, G. (2019). Man who died in airbag malfunction would have been quadriplegic if he survived, inquest told. The Sydney Morning Herald. Retrieved from https://www.smh.com.au/national/nsw/man-who-died-inairbag-malfunction-would-have-been-quadriplegic-if-he-survived-inquest-told-20190924-p52ucy.html. Accessed 5 May 2020.

Morabito, V. (2017). An empirical study of Australia's class action regimes, fifth report: The first twenty-five years of class actions in Australia. Stanford University Global Class Actions Exchange (July 20, 2017). Retrieved from http://globalclassactions.stanford.edu/content/empirical-study-australias-class-actionregimesfifth-report-first-twenty-five-years-class-a. Accessed 5 May 2020.

Nagy, C. I. (2019). Collective actions in Europe: A comparative, economic and transsystemic analysis. Cham: Springer Nature.

Niven, C. M., Mathews, B., Harrison, J. E., \& Vallmuur, K. (2019). Hazardous children's products on the Australian and US market 2011-2017: An empirical analysis of child-related product safety recalls. Injury Prevention, injuryprev-2019-043267.

Nottage, L. (2004). Product safety and liability law in Japan: From Minamata to mad cows. Oxford: Routledge.

Nottage, L. R. (2011). Suppliers' duties to report product-related accidents under the new "Australian Consumer Law": A comparative critique. Commercial Law Quarterly, 25(2), 3-14.

Nottage, L., \& Kozuka, S. (2012). Lessons from product safety regulation for reforming consumer credit markets in Japan and beyond. Sydney Law Review, 34, 129.

Nottage, L. (2014). Policy digest 2: Consumer product safety regulation - Recalls and accident information disclosure mechanisms. In ASEAN Secretariat, Consumer protection digests and case studies: A policy guide (vol. 1, pp. 15-24). Retrieved from www.aseanconsumer.org/accp/uploads/files/CPDCS_PGV1.pdf. Accessed 5 May 2020.

Nottage, L. (2016). Adding a "general safety provision" to consumer law in Australia (and Japan)?. Japanese Law and the Asia-Pacific. Retrieved from https://japaneselaw.sydney.edu.au/2016/12/adding-a-generalsafety-provision-to-consumer-law-in-australia-and-japan/. Accessed 5 May 2020.

Nottage, L. \& Niven, C. (2017). Reforming product safety law: Good and bad news from the Australian Consumer Law review. Japanese Law and the Asia-Pacific. Retrieved from https://japaneselaw.sydney. edu.au/2017/07/reforming-product-safety-law-good-and-bad-news-from-the-australian-consumer-lawreview/. Accessed 5 May 2020.

Nottage, L. (2018). Product safety regulation. In Handbook of research on international consumer law (second ed.). Cheltenham: Edward Elgar.

Nottage, L. R., \& Paterson, J. M. (2019). Consumer contracts and product safety law in Southeast Asia: Partly trading up? In P. L. Hsieh \& B. Mercurio (Eds.), ASEAN law in the new regional economic order. Cambridge: Cambridge University Press.

Nottage, L., Malbon, J., Paterson, J., \& Beaton-Wells, C. (2019). ASEAN consumer law harmonisation and cooperation: Achievements and challenges (Vol. 18). Cambridge: Cambridge University Press.

OECD. (2020). Global portal on product recalls. Retrieved from https://globalrecalls.oecd.org/\#/. Accessed 5 May 2020.

OECD. (2019). Global awareness campaign on product recalls. Retrieved from http://www.oecd. org/sti/consumer/product-recalls/ (Accessed 5 May 2020).

OECD. (n.d.). Worldwide snapshot of recalled products. Retrieved from http://www.oecd. org/sti/consumer/product-recalls/worldwide-snapshot-of-recalled-products.pdf. Accessed 5 May 2020.

OECD. (2017). The Australian Competition and Consumer Commission recalls toys from Daiso Industries (Australia) Pty Ltd. Global portal on product recalls. Retrieved from https://globalrecalls.oecd. org/\#/recalls/http\%3A\%2F\%2FPoliciesApplications.oecd.org\%2FGlobalRecalls\%2FRecall\%2FEN\%2 FSG\%2FD1A3QXBXDKXYTZAXV2JUSMLYV2VGDZ09. Accessed 5 May 2020.

Paterson, J. (2016). The consumer guarantee remedial regime: Some uncertainties and the role of common law analogy. Journal of Contract Law, 33, 210.

Productivity Commission. (2006). Review of the Australian consumer product safety system. Retrieved from https://www.pc.gov.au/inquiries/completed/consumer-product-safety/report. Accessed 5 May 2020.

Productivity Commission. (2008). Review of Australia's consumer policy framework. Retrieved from https://www.pc.gov.au/inquiries/completed/consumer-product-safety/report. Accessed 5 May 2020.

Productivity Commission (2017). Consumer law enforcement and administration. Retrieved from https:/www. pc.gov.au/inquiries/completed/consumer-law\#report. Accessed 5 May 2020.

Ramseyer, J. M. (1996). Products liability through private ordering: Notes on a Japanese experiment. University of Pennsylvania Law Review, 144(5), 1823-1840.

Reimann, M. (2003). Liability for defective products at the beginning of the twenty-first century: Emergence of a worldwide standard. American Journal Comparative Law, 51, 751.

The Canberra Times. (2019). Takata airbag recall delays are a disgrace. Retrieved from https://www. canberratimes.com.au/story/6423207/takata-airbag-recall-delays-are-a-disgrace/. Accessed 5 May 2020. 
Tilleke \& Gibbins. (2019). Cambodia enacts a new e-commerce law and a consumer protection law. Retrieved from https://www.tilleke.com/resources/cambodia-enacts-new-e-commerce-law-and-consumer-protectionlaw. Accessed 5 May 2020.

Transdirect. (2020). The exploding growth of ecommerce in Australia: 4 statistics you need to know. Retrieved from https://www.transdirect.com.au/blog/aus-ecommerce-stats. Accessed 5 May 2020.

Treasury. (2019a). Consultation regulation impact statement: Improving the effectiveness of the consumer product safety system. Retrieved from https://consult.treasury.gov.au/market-and-competition-policydivision-internal/main-consultation/. Accessed 5 May 2020.

Treasury. (2019b). Government response to the final report of the Royal Commission into Misconduct in the Banking, Superannuation and Financial Services Industry Retrieved from https://reasury.gov. au/publication/p2019-fsrc-response (accessed 5 May 2020).

Treasury. (n.d.). Australian Consumer Law review. Australian Consumer Law. Retrieved from https://consumerlaw.gov.au/consultations-and-reviews/australian-consumer-law-review. Accessed 5 May 2020.

Treasury. (2016). Australian consumer survey. Australian Consumer Law. Retrieved from https://consumerlaw. gov.au/consultations-and-reviews/australian-consumer-survey. Accessed 5 May 2020.

U.S. Government Accountability Office (GAO). (2013). Consumer Product Safety Commission: Awareness, use, and usefulness of saferproducts.gov. Retrieved from https://www.gao.gov/products/gao-13-306. Accessed 5 May 2020.

WebAlive. (2019). The state of Australia's ecommerce in 2019. Retrieved from https://www.webalive.com. au/ecommerce-statistics-australia/. Accessed 5 May 2020.

Wei, D. (2020). From fragmentation to harmonization of consumer law: The perspective of China. Journal of Consumer Policy, 43, 1-22.

Zakaria, Z. (2015). Regulation of cosmetics: What has Malaysia learnt from the European system? Journal of Consumer Policy, 38(1), 39-59.

ZICO. (2019). Myanmar: Consumer Protection Law 2019. Retrieved from https://zico.group/blog/myanmarconsumer-protection-law-2019/. Accessed 5 May 2020.

\section{Cases}

ACCC v Thermomix [2018] FCA 556

ACCC v Woolworths [2016] FCA 44

\section{Legislation}

\section{Australia}

Australian Consumer Law: Schedule 2 of the Competition and Consumer Act 2010 (Cth)

\section{Canada}

Canada Consumer Product Safety Act 2010

\section{European Union}

Directive 2001/95/EC on General Product Safety (2001) OJ L 11/4

Directive 92/59/EEC on General Product Safety (1992) OJ L 228/24 


\section{Hong Kong}

Consumer Goods Safety Ordinance 1995

\section{Japan}

Consumer Product Safety Act 1973

\section{Laos}

Consumer Protection Act 2010

\section{Malaysia}

Consumer Protection Act 1999

\section{Myanmar}

Consumer Protection Law 2014

Consumer Protection Law 2019

\section{Singapore}

Consumer Protection (Consumer Goods Safety Requirements) Regulations 2011

\section{UK}

Consumer Protection Act 1987

General Product Safety Regulations 2005

\section{Vietnam}

Law on Protection of Consumers' Rights 2010

Publisher's Note Springer Nature remains neutral with regard to jurisdictional claims in published maps and institutional affiliations.

\section{Affiliations}

\section{Nottage ${ }^{1}$}

1 Sydney Law School, University of Sydney, Sydney, NSW 2006, Australia 